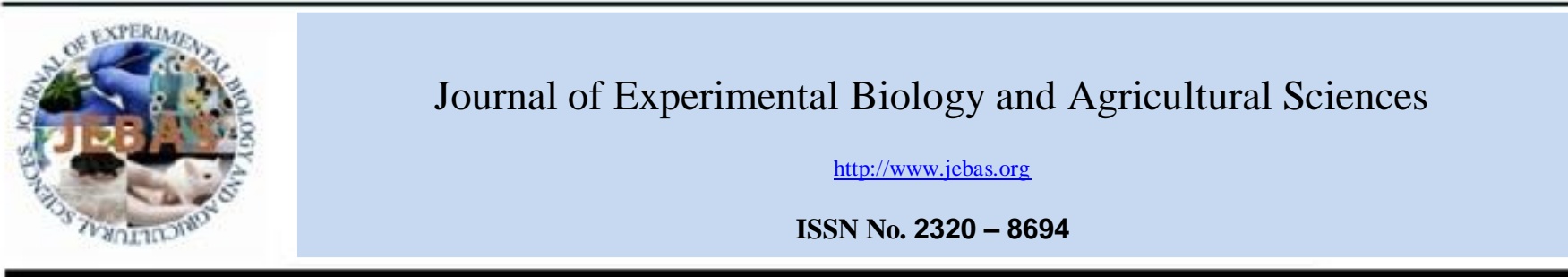

\title{
INFLUENCE OF DIFFERENT LEVEL OF WATER AND FERTILIZER APPLICATION THROUGH DRIP SYSTEM ON GROWTH AND YIELD OF KINNOW MANDARIN (Citrus reticulata BLANCO)
}

\author{
Vijaya H.M.*, R.K.Godara, Shashank Singh and Nidhi Sharma \\ Department of Horticulture, CCS HAU, Hisar - 120004
}

Received - September 04, 2017; Revision - October 15, 2017; Accepted - December 04, 2017

Available Online - December 27, 2017

DOI: http://dx.doi.org/10.18006/2017.5(6).840.845

\section{KEYWORDS \\ Drip irrigation \\ Fertigation \\ Growth \\ Yield}

Kinnow mandarin

\begin{abstract}
A field experiment was conducted at fruit orchard, Department of Horticulture, CCS HAU, Hisar to standardize the optimum level of water and NPK fertilizers through drip system for the sustained production of Kinnow mandarin under semi-arid condition of Haryana. The experiment was designed in factorial RBD with three replications and consisted of twelve treatment combinations, involving of three drip irrigation regimes (1.0, 0.8 and 0.6 volume of water) and four RDF levels of NPK $(120 \%, 100 \%$, $80 \%$ and $60 \% \mathrm{RDF})$. Significantly highest gain in plant growth parameters viz., plant height $(48.8 \mathrm{~cm})$, stem girth $(6.24 \mathrm{~cm})$ and plant spread $(40.1 \mathrm{~cm})$ was observed with the combined application of drip irrigation at 1.0 volume of water and $120 \%$ RDF through fertigation, whereas, highest number of fruits (515.9) and yield per hectare (258.7 quintals) was registered with the interaction effect of 0.8 volume of water and $80 \%$ RDF through drip irrigation.
\end{abstract}

* Corresponding author

E-mail: hmvijay2010@gmail.com (Vijaya.H.M)

Peer review under responsibility of Journal of Experimental Biology and Agricultural Sciences.

Production and Hosting by Horizon Publisher India [HPI] (http://www.horizonpublisherindia.in/).

All rights reserved.
All the article published by Journal of Experimental Biology and Agricultural Sciences is licensed under a Creative Commons Attribution-NonCommercial 4.0 International License Based on a work at www.jebas.org.

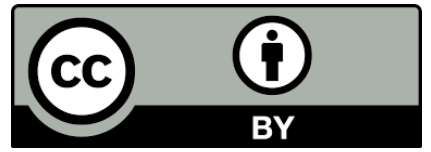




\section{Introduction}

Kinnow mandarin (Citrus reticulata Blanco), a man-made hybrid between King mandarin (Citrus nobilis Lour.) and Willow leaf mandarin (C. deliciosa Tan.) has become one of the most important commercial crops cultivated in Northern part of India due to increased demand in both domestic as well as in international markets (Gera, 2014 \& Chaba, 2017). It is extensively grown in semi-arid regions of Punjab, Haryana, northwestern parts of Rajasthan and Uttar Pradesh (Ahmad \& Siddiqui, 2015). Flood irrigation is predominantly practiced in various Kinnow orchards of India. However, the use efficiency of water in flood irrigation method is very less due to excess loss of water through conveyance, percolation, evaporation and distribution (Shirgure, 2012). Adoption of trickle irrigation would increase the water use efficiency up to $95 \%$ while maintaining higher yield (Pattanaaik, 2017). Similarly lower use efficiencies of fertilizers with the traditional fertilizer application methods is noticed due to significant losses of nutrients by leaching, run-off, gaseous emission and fixation by soil. Fertigation has many advantages over applying water and fertilizer separately, such as increased mobility of nutrients, reduced fertilizer and water, effective nutrient placement and flexibility in application frequency in addition to development of uniform root distribution. Besides these benefits, fertigation also reduces the potential of groundwater contamination caused by fertilizer leaching (Gärdenäs et al., 2005). The impact of drip irrigation and drip fertigation had been studied in different citrus cultivars under various agro-climatic zones in India (Kusakabe et al., 2006; Navarro \& Falivene, 2015; Shirgure et al., 2016; Panigrahi \& Srivastava, 2017) empathizing the enhanced water and nutrient use efficiency compared with traditional method of surface irrigation along with broadcasting or band placement of fertilizer in tree basins. In Haryana, where brackish underground water and canal water are common source of irrigation due to poor distribution of rainfall, the adoption of drip irrigation and fertigation could save substantial quantity of both water and fertilizers. However, no information is available regarding optimal irrigation and fertilizer schedule through drip and the performance of drip-fertigation compared to traditional irrigation and fertilizer application in Kinnow mandarin. Keeping above details in perspective, the present study was carried out to irrigation and fertilizer application through drip irrigation.

\section{Material and Methods}

The experiment was conducted during 2014 at the experimental block of Department of Horticulture, CCS HAU, Hisar, Haryana, located at an elevation of $211.3 \mathrm{~m}$ above mean sea level. The meteorological data of the experimental site observed during the period of investigation is graphically presented (Figure 1). The six-years-old Kinnow mandarin plants planted at $6 \mathrm{~m} \times 6 \mathrm{~m}$ distance were used as experimental material. The orchard having 144 trees, which were divided into 36 treatment plots with each four Kinnow plants. The experiment comprised of twelve treatment combinations, involving three irrigation levels $(1.0 \mathrm{~V}$,

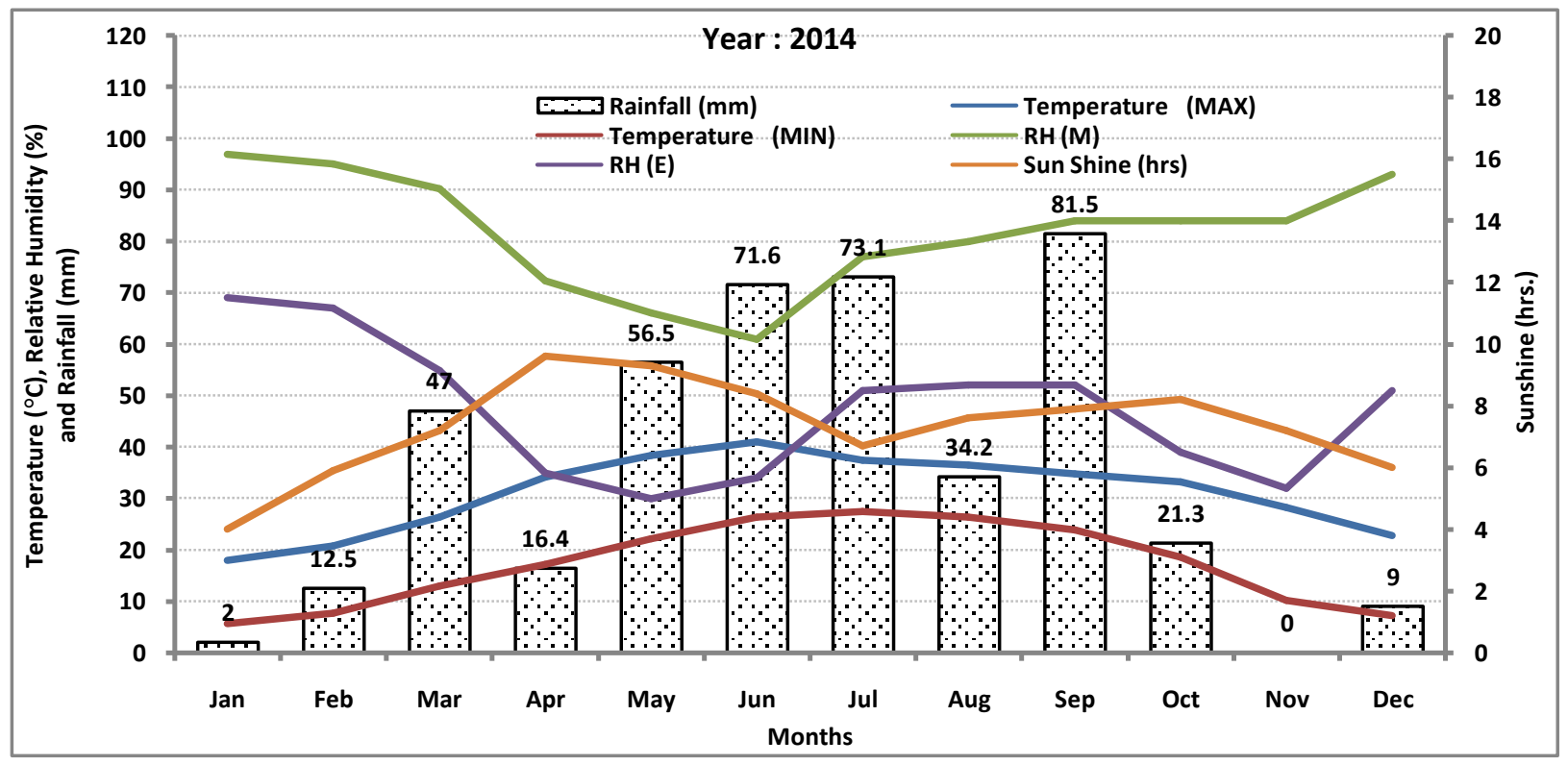

Figure 1 Meteorological data of the experimental orchard at CCS HAU, Hisar recorded during cropping season 
$0.8 \mathrm{~V}$ and $0.6 \mathrm{~V})$ and four fertigation levels (120\% RDF, $100 \%$ RDF, $80 \%$ RDF and $60 \% \mathrm{RDF}$ ). Each treatment was replicated thrice in the experiment. Three trees having uniform size and vigour were tagged in every plot before allocation of treatments (total 108 plants) and the observations were recorded. The initial characteristics of soil data shows that the experimental site was slightly alkaline in reaction, medium in organic carbon and available phosphorus, low soil nitrogen and high in available potash content as per the limits suggested by Antil et al. (2002). The drip irrigation in respective treatments was carried out daily on the basis of weekly average evaporation data of past 35 years and consumptive water requirement of the crop (Domingo et al., 1996). Irrigation quantity for different drip irrigation regimes was computed using the equation given below. The quantity of water applied under different irrigation regimes was regulated by adjusting the operating time (Kumar et al., 2013).

$$
\begin{gathered}
\mathrm{V}=\mathrm{ETc}-(\operatorname{Re} \times \mathrm{A}) \\
\mathrm{V}=(\mathrm{Ep} \times \mathrm{Kc} \times \mathrm{Kp} \times \mathrm{Wp} \times \mathrm{A} \times \mathrm{N})-(\operatorname{Re} \times \mathrm{A})
\end{gathered}
$$

Whereas $V=$ Irrigation volume (litres irrigation ${ }^{-1}$ ), ETc $=$ Crop evapotranspiration $\left(\right.$ litres $^{-1}$ tree $^{-1} N$ days $^{-1}$ ), Ep $=$ Mean pan evaporation ( $\mathrm{mm}$ day $^{-1}$ for $\mathrm{N}$ days), $\mathrm{Kc}=\mathrm{Crop}$ factor, $\mathrm{Kp}=$ Pan factor, Wp $=$ Wetted area Plant area ${ }^{-1}, A=$ Area per plant $\left(\mathrm{m}^{2}\right)$, $N=$ Number of days, $R e=$ Effective rainfall $(\mathrm{mm})$

Fertigation of NPK fertilizers was accomplished using venturi injector. The recommended dose of fertilizers for Kinnow mandarin under Haryana conditions is $348 \mathrm{~g} \mathrm{~N}, 240 \mathrm{~g} \mathrm{P}_{2} \mathrm{O}_{5}$ and $270 \mathrm{~g} \mathrm{~K}_{2} \mathrm{O}$ plant $^{-1}$ year $^{-1}$ (Anonymous, 2013). The fertigation was carried out during scheduled irrigation to replenish the soil moisture and to ensure that all treatments received uniform irrigation during the fertigation events. Fertigation was done in eight split doses at monthly interval (Anonymous, 2007). In order to maintain the plant in healthy condition, the recommended package of practices and plant protection measures were followed. Plant growth parameters were measured twice viz., at start of the experiment (during February) and after the crop harvest (during December month). The plant height in each treatment was measured from the base of trunk to the tip of the terminal extension growth using a bamboo pole. The stem girth was recorded by employing a measuring tape at a point marked above $15 \mathrm{~cm}$ from the ground level, whereas, the plant spread was recorded by measuring the canopy spread in both east-west and north-south directions with the help of a bamboo pole. The average plant spread in both the directions (East-West and NorthSouth) was taken as total spread of the trees. The average annual increment in each growth parameter was calculated and expressed in centimeter. The fruit and yield data were recorded during harvesting season (December month).

The statistical analysis of data was carried out in factorial analysis of variance (ANOVA) using OrigiPro statistical software (OriginLab, Northampton, Massachusetts). The critical differences $(\mathrm{P}<0.05)$ was used for separation of treatment means.

\section{Results and Discussion}

\subsection{Growth parameters}

The average annual increment in plant growth parameters in relation to different drip irrigation and fertigation treatments are presented in Table 1. Among irrigation treatments, significantly highest increment in plant height $(41.4 \mathrm{~cm})$, stem girth $(5.68 \mathrm{~cm})$ and plant spread $(34.8 \mathrm{~cm})$ were obtained with drip irrigation at

\begin{tabular}{|c|c|c|c|c|c|c|c|}
\hline Treatments & $\begin{array}{l}\text { Increment in } \\
\text { plant height } \\
(\mathrm{cm})\end{array}$ & $\begin{array}{l}\text { Increment in } \\
\text { stem girth } \\
(\mathrm{cm})\end{array}$ & $\begin{array}{l}\text { Increment in } \\
\text { plant spread } \\
\text { (cm) }\end{array}$ & $\begin{array}{c}\text { Number of } \\
\text { fruits per } \\
\text { plant }\end{array}$ & $\begin{array}{c}\text { Fruit } \\
\text { diameter }(\mathbf{c m})\end{array}$ & $\begin{array}{c}\text { Fruit weight } \\
\text { (g) }\end{array}$ & $\begin{array}{c}\text { Fruit yield } \\
\left(\mathbf{q} \mathbf{h a}^{-1}\right)\end{array}$ \\
\hline \multicolumn{8}{|c|}{ Irrigation Levels } \\
\hline $\mathrm{I}_{1}$ & $41.4 \pm 0.8^{\mathrm{a}}$ & $5.68 \pm 0.02^{\mathrm{a}}$ & $34.8 \pm 1.2^{\mathrm{a}}$ & $470.9 \pm 1.7^{\mathrm{b}}$ & $7.34 \pm 0.02^{\mathrm{b}}$ & $170.0 \pm 0.7^{\mathrm{b}}$ & $223.2 \pm 1.2^{\mathrm{b}}$ \\
\hline $\mathrm{I}_{2}$ & $39.2 \pm 0.1^{\mathrm{b}}$ & $5.48 \pm 0.05^{\mathrm{b}}$ & $32.9 \pm 0.9^{\mathrm{a}}$ & $488.7 \pm 6.2^{\mathrm{a}}$ & $7.48 \pm 0.01^{\mathrm{a}}$ & $173.2 \pm 0.5^{\mathrm{a}}$ & $236.0 \pm 3.3^{\mathrm{a}}$ \\
\hline $\mathrm{I}_{3}$ & $28.9 \pm 0.9^{\mathrm{c}}$ & $4.36 \pm 0.03^{\mathrm{b}}$ & $22.6 \pm 1.0^{\mathrm{b}}$ & $384.4 \pm 2.2^{\mathrm{c}}$ & $6.8 \pm 0.04^{\mathrm{c}}$ & $146.7 \pm 0.8^{\mathrm{c}}$ & $157.0 \pm 0.6^{\mathrm{c}}$ \\
\hline \multicolumn{8}{|c|}{ Fertigation Levels } \\
\hline $\mathrm{F}_{1}$ & $41.9 \pm 0.5^{\mathrm{a}}$ & $5.69 \pm 0.06^{\mathrm{a}}$ & $34.2 \pm 0.7^{\mathrm{a}}$ & $461.6 \pm 5.8^{\mathrm{a}}$ & $7.30 \pm 0.01^{b}$ & $168.3 \pm 1.8^{\mathrm{a}}$ & $217.7 \pm 4.4^{\mathrm{a}}$ \\
\hline $\mathrm{F}_{2}$ & $39.7 \pm 1.1^{\mathrm{b}}$ & $5.51 \pm 0.05^{\mathrm{a}}$ & $32.6 \pm 2.3^{\mathrm{ab}}$ & $463.6 \pm 3.7^{\mathrm{a}}$ & $7.32 \pm 0.03^{\mathrm{a}}$ & $167.9 \pm 0.8^{\mathrm{a}}$ & $218.2 \pm 1.3^{\mathrm{a}}$ \\
\hline $\mathrm{F}_{3}$ & $35.3 \pm 0.7^{\mathrm{c}}$ & $5.01 \pm 0.09^{\mathrm{b}}$ & $29.9 \pm 0.5^{b}$ & $456.0 \pm 3.5^{\mathrm{a}}$ & $7.27 \pm 0.04^{\mathrm{c}}$ & $166.8 \pm 1.1^{\mathrm{a}}$ & $213.4 \pm 1.7^{\mathrm{a}}$ \\
\hline $\mathrm{F}_{4}$ & $29.0 \pm 0.6^{\mathrm{d}}$ & $4.48 \pm 0.03^{\mathrm{c}}$ & $23.6 \pm 0.7^{\mathrm{c}}$ & $410.7 \pm 6.1^{b}$ & $6.93 \pm 0.01^{\mathrm{d}}$ & $150.3 \pm 0.7^{\mathrm{b}}$ & $172.4 \pm 3.2^{\mathrm{b}}$ \\
\hline
\end{tabular}

Table 1 Effect of different level of drip irrigation and fertigation on growth and yield of Kinnow mandarin

Means followed by the same letter in each parameter is not significantly different $(P<0.05), I 1, I 2 \& I 3$ drip irrigation at $1.0 \mathrm{~V}, 0.8 \mathrm{~V}$ and $0.6 \mathrm{~V}$, whereas, F1, F2, F3 \& F4 fertigation at $120 \%$ RDF, $100 \%$ RDF, $80 \%$ RDF and $60 \%$ RDF, respectively. 
1.0 volume of water, whereas, the lowest improvement in vegetative growth viz., plant height $(28.9 \mathrm{~cm})$, stem girth $(4.36$ $\mathrm{cm})$ and plant spread $(22.6 \mathrm{~cm})$ was noticed under $0.6 \mathrm{~V}$ of irrigation. The maximum growth with highest irrigation level could be attributed to availability of sufficient moisture that led to the better development of photosynthetic area, accelerated photosynthetic rate and eventually amplified plant growth. The highest level of vegetative growth with increased level of irrigation was reflective of the outcome of the experiment carried out by Panigrahi et al. (2012) in Nagpur mandarin. Limited growth under $0.6 \mathrm{~V}$ irrigation level attributed to negative effects of water inadequacy caused on photosynthesis, resulting in reduced cell elongation and growth. The analogous results were earlier obtained by Chauhan \& Chandel (2008) and Kumar et al. (2013) in Kiwifruit and sweet orange cv. Mosambi, respectively. In different fertigation treatments, maximum gain in plant growth (plant height, stem girth and plant spread) were observed with the application of $120 \%$ RDF through drip irrigation, whereas lowest gain in plant growth was found with the application of $60 \%$ RDF. Plant growth was gradually increased with increased fertigation level. The greater vegetative growth at higher dose of fertigation might be due to increased availability of nutrients in the root zone as the NPK nutrients from the basis of fundamental constituents of all living plants. Wassel et al., (2007) and Haneef et al., (2014) reported higher magnitude of growth with enhanced absorption of major nutrients through fertigation.

The interaction between drip irrigation and fertigation levels significantly affected the plant height and stem girth. The highest gain in plant height $(48.8 \mathrm{~cm})$ and stem girth $(6.24 \mathrm{~cm})$ was exhibited with irrigation at 1.0 volume of water and $120 \%$ RDF, followed by the treatment involving $1.0 \mathrm{~V}$ irrigation $+100 \% \mathrm{RDF}$. However, increment in plant spread was not influenced significantly due to interaction of different irrigation and fertigation treatments. Greater improvement in vegetative growth at higher treatment level was possibly due to sufficient and continuous availability of moisture along with major nutrients (NPK) contributing towards vegetative development of plants as a result of higher partitioning of photosynthates, better photosynthetic area and cell turgidity. These observations corroborated with the findings of Joshi et al. (2012) and Kumar et al. (2013), who also obtained higher growth with increased amount of water and fertilizers in litchi and sweet orange, respectively.

\subsection{Yield parameters}

It is evident from the table that the significantly higher number of fruits (488.7), maximum fruit weight (173.2 $\mathrm{g}$ ) and fruit diameter $(7.48 \mathrm{~cm})$ was observed with $0.8 \mathrm{~V}$ of irrigation. While, the minimum number of fruits (384.4), lesser fruit weight (146.7 g) and fruit diameter $(6.8 \mathrm{~cm})$ were recorded with $0.6 \mathrm{~V}$ drip irrigation. The highest number of fruits with $0.8 \mathrm{~V}$ irrigation might be due to constant and adequate availability of moisture in plant rhizosphere during fruit developmental stages that eventually enhanced the fruit retention capacity of plant. The importance of regular and appropriate supply of water during fruit development stages was highlighted earlier by Subramanian et al. (1997), Panigrahi et al. (2012) and Ghosh \& Pal (2016). Further, Sezen et al. (2015) also reported a gradual increases in yield with increased level of irrigation, while, Kumar et al. (2013) reported a significant reduction in the number of fruits and fruit yield with highest irrigation level. At highest irrigation level (1.0V), the number of fruits and fruit weight was reduced. Regarding fruit yield, it was greater with irrigation level at $0.8 \mathrm{~V}$, largely as a consequence of maximum number of fruits and higher fruit weight in the treatment. The different fertigation levels significantly influenced the fruit yield. The maximum number of fruits per tree was harvested from the plants supplied with $100 \%$ RDF (486.5), which is closely followed by $120 \%$ RDF (482.7) and $80 \%$ RDF (477.4). Yield contributing characters and yield were improved with increase in fertigation level from $60 \%$ to $100 \%$ RDF. Further increase in RDF levels had no significant impact on the number of fruits, fruit weight and fruit yield. However, the response was statistically similar with those of $100 \%$ and $120 \% \mathrm{RDF}$, indicating that $80 \% \mathrm{RDF}$ was sufficient for sustaining the productivity. These results are in line with the findings of Murthy (1997) in grape.

Different combination of irrigation and fertigation treatments had an appreciable impact on number of fruits per plant. Maximum number of fruits per tree was registered when 0.8 volume of water combined with fertigation with $80 \%$ RDF (515.9). This treatment was numerically similar with combined effect of drip irrigation at $0.8 \mathrm{~V}+100 \%$ fertigation (508.34) and drip irrigation at $1.0 \mathrm{~V}+$ $120 \%$ fertigation (502.8). Interaction effect of irrigation at $0.6 \mathrm{~V}$ and $60 \%$ RDF had least number of fruits per tree (378.3). The heavier fruits and higher fruit diameter was recorded with $0.8 \mathrm{~V}$ irrigation $+80 \%$ RDF fertigation. Data presented in Table 2 also reveals that highest fruit yield $\left(258.7 \mathrm{q} \mathrm{ha}^{-1}\right)$ was obtained with interaction effect of $0.8 \mathrm{~V}$ irrigation $+80 \% \mathrm{RDF}$, being numerically at par with $0.8 \mathrm{~V}$ irrigation $+100 \%$ RDF $\left(252.5 \mathrm{q} \mathrm{ha}^{-}\right.$ $\left.{ }^{1}\right)$ and $1.0 \mathrm{~V}$ irrigation $+120 \% \operatorname{RDF}\left(247.2 \mathrm{q} \mathrm{ha}^{-1}\right)$. However, the treatment with $0.8 \mathrm{~V}$ irrigation $+80 \% \mathrm{RDF}$ appeared to be more viable as it saved $20 \%$ of RDF. The higher yield realized under these treatments was due to better photosynthesis in the leaves caused by consistent availability of water for absorption, excellent soil-water-air relationship and better uptake of nutrient elements, resulting in proper translocation of food material. The views of Panigrahi \& Srivastava (2017) and Shirgure et al. (2016) in Nagpur mandarin and Suman \& Raina (2014) in apple are in support of the present findings. 
Table 2 Combined effect of different drip irrigation and fertigation treatments on growth and yield of Kinnow mandarin

\begin{tabular}{|ccc|ccccc|}
\hline Treatments & $\begin{array}{c}\text { Increment in } \\
\text { plant height } \\
(\mathbf{c m})\end{array}$ & $\begin{array}{c}\text { Increment in } \\
\text { stem girth } \\
(\mathbf{c m})\end{array}$ & $\begin{array}{c}\text { Increment } \\
\text { in plant } \\
\text { spread }(\mathbf{c m})\end{array}$ & $\begin{array}{c}\text { Number of } \\
\text { fruits } \\
\text { per plant }\end{array}$ & $\begin{array}{c}\text { Fruit } \\
\text { diameter } \\
(\mathbf{c m})\end{array}$ & $\begin{array}{c}\text { Fruit weight } \\
(\mathbf{g})\end{array}$ & $\begin{array}{c}\text { Fruit yield } \\
(\mathbf{q} \text { ha }\end{array}$ \\
\hline $\mathrm{I}_{1} \mathrm{~F}_{1}$ & $48.8 \pm 1.2^{\mathrm{a}}$ & $6.24 \pm 0.08^{\mathrm{a}}$ & $40.1 \pm 2.3$ & $502.8 \pm 12.8^{\mathrm{abc}}$ & $7.47 \pm 0.03$ & $176.8 \pm 2.3^{\mathrm{abcd}}$ & $247.2 \pm 8.0^{\mathrm{abc}}$ \\
\hline $\mathrm{I}_{1} \mathrm{~F}_{2}$ & $45.9 \pm 1.1^{\mathrm{ab}}$ & $6.09 \pm 0.08^{\mathrm{ab}}$ & $38.3 \pm 2.3$ & $488.7 \pm 7.7^{\mathrm{bcd}}$ & $7.45 \pm 0.06$ & $175.1 \pm 1.0^{\text {abcde }}$ & $237.9 \pm 5.1^{\mathrm{cd}}$ \\
\hline $\mathrm{I}_{1} \mathrm{~F}_{3}$ & $37.6 \pm 1.6^{\mathrm{e}}$ & $5.31 \pm 0.18^{\mathrm{ef}}$ & $32.4 \pm 1.6$ & $464.5 \pm 10.8^{\text {ef }}$ & $7.39 \pm 0.03$ & $172.7 \pm 0.8^{\text {cdef }}$ & $222.9 \pm 4.7$ \\
\hline $\mathrm{I}_{1} \mathrm{~F}_{4}$ & $33.1 \pm 1.5^{\mathrm{f}}$ & $5.08 \pm 0.10^{\mathrm{fg}}$ & $28.3 \pm 1.6$ & $427.6 \pm 9.7^{\mathrm{g}}$ & $7.03 \pm 0.06$ & $155.5 \pm 2.4^{\mathrm{gh}}$ & $184.9 \pm 6.8^{\mathrm{e}}$ \\
\hline $\mathrm{I}_{2} \mathrm{~F}_{1}$ & $44.2 \pm 1.1^{\mathrm{bc}}$ & $6.01 \pm 0.10^{\mathrm{abc}}$ & $37.1 \pm 1.3$ & $487.0 \pm 8.4^{\mathrm{cde}}$ & $7.51 \pm 0.02$ & $177.6 \pm 1.3^{\mathrm{abc}}$ & $240.5 \pm 5.0^{\mathrm{bcd}}$ \\
\hline $\mathrm{I}_{2} \mathrm{~F}_{2}$ & $42.0 \pm 1.2^{\mathrm{cd}}$ & $5.84 \pm 0.11^{\mathrm{bcd}}$ & $34.8 \pm 2.2$ & $508.3 \pm 9.1^{\mathrm{ab}}$ & $7.62 \pm 0.02$ & $178.7 \pm 2.2^{\mathrm{ab}}$ & $252.5 \pm 4.5^{\mathrm{ab}}$ \\
\hline $\mathrm{I}_{2} \mathrm{~F}_{3}$ & $39.5 \pm 0.8^{\mathrm{de}}$ & $5.56 \pm 0.11^{\mathrm{de}}$ & $35.1 \pm 1.4$ & $515.9 \pm 4.5^{\mathrm{a}}$ & $7.60 \pm 0.03$ & $180.4 \pm 0.9^{\mathrm{a}}$ & $258.7 \pm 3.4^{\mathrm{a}}$ \\
\hline $\mathrm{I}_{2} \mathrm{~F}_{4}$ & $31.0 \pm 1.3^{\mathrm{fh}}$ & $4.49 \pm 0.08^{\mathrm{i}}$ & $24.6 \pm 1.0$ & $443.6 \pm 8.9^{\mathrm{fg}}$ & $7.21 \pm 0.08$ & $156.0 \pm 2.0^{\mathrm{fg}}$ & $192.3 \pm 1.8^{\mathrm{e}}$ \\
\hline $\mathrm{I}_{3} \mathrm{~F}_{1}$ & $32.9 \pm 1.4^{\mathrm{fg}}$ & $4.81 \pm 0.12^{\mathrm{gh}}$ & $25.5 \pm 1.8$ & $395.1 \pm 5.0^{\mathrm{h}}$ & $6.93 \pm 0.05$ & $150.5 \pm 1.9^{\mathrm{ghi}}$ & $165.3 \pm 3.8^{\mathrm{f}}$ \\
\hline $\mathrm{I}_{3} \mathrm{~F}_{2}$ & $31.1 \pm 1.7^{\mathrm{fghi}}$ & $4.60 \pm 0.14^{\mathrm{hi}}$ & $24.8 \pm 2.7$ & $393.9 \pm 3.2^{\mathrm{hi}}$ & $6.90 \pm 0.09$ & $149.9 \pm 1.2^{\mathrm{hij}}$ & $164.2 \pm 2.5^{\mathrm{fg}}$ \\
\hline $\mathrm{I}_{3} \mathrm{~F}_{3}$ & $28.9 \pm 1.2^{\mathrm{i}}$ & $4.16 \pm 0.04$ & $22.3 \pm 1.5$ & $387.5 \pm 9.1^{\mathrm{hi}}$ & $6.82 \pm 0.10$ & $147.3 \pm 4.2^{\mathrm{ij}}$ & $158.5 \pm 2.6^{\mathrm{fg}}$ \\
\hline $\mathrm{I}_{3} \mathrm{~F}_{4}$ & $22.9 \pm 1.3$ & $3.88 \pm 0.06$ & $17.8 \pm 0.5$ & $361.1 \pm 4.7$ & $6.57 \pm 0.04$ & $139.3 \pm 0.9$ & $139.9 \pm 1.9$ \\
\hline
\end{tabular}

Means followed by the same letter in each parameter is not significantly different $(P<0.05), I 1, I 2 \& I 3$ drip irrigation at $1.0 \mathrm{~V}, 0.8 \mathrm{~V}$ and $0.6 \mathrm{~V}$, whereas, F1, F2, F3 \& F4 fertigation at $120 \%$ RDF, $100 \%$ RDF, $80 \%$ RDF and $60 \%$ RDF, respectively.

\section{Conclusion}

The application of water and fertilizers through drip system could save substantial quantity of irrigation water and fertilizers. Combined application of drip irrigation at $0.8 \mathrm{~V}$ of water and $80 \%$ of RDF found to be efficient in sustained Kinnow production under Hisar condition as it recorded significantly highest number of fruits (515.9), fruit weight (180.4 g) and fruit yield $\left(258.7 \mathrm{q} \mathrm{ha}^{-1}\right)$ over other treatment combinations

\section{Conflict of Interest}

Authors would hereby like to declare that there is no conflict of interests that could possibly arise.

\section{References}

Ahmad MS, Siddiqui MW (2015) Growing Areas and Harvesting Season of Commercially Important Fruits. In: Postharvest Quality Assurance of Fruits, Springer International Publishing. Pp. 47-60.

Anonymous (2007) Improvement and management of horticultural crops, DARE/ICAR Annual Report, ICAR, New Delhi 2006-2007, Pp. 43-44.

Anonymous (2013) Package of Practices for Horticultural crops (in Hindi). Directorate of Extension Education, CCS HAU Publication, Hisar, India.
Antil RS, Singh A, Dahiya SS (2002) Collection and processing of soil samples and plant samples. Practical Manual for soil and plant analysis, CCS HAU Publication, Pp.71.

Chaba AA (2017) Kinnow expects three-fold hike in exports. Indian Express. Retrieved from $\mathrm{http} / / /$ indianexpress.com/article/india/kinnow-exports-fruitskinnow-expects-three-fold-hike-in-exports-4514938/ access on $29^{\text {th }}$ April, 2017.

Chauhan N, Chandel JS (2008) Effect of fertigation on growth, yield, fruit quality and fertilizer-use efficiency of Kiwifruit (Actinidia deliciosa). Indian Journal of Agricultural Sciences 78: 389-393.

Domingo R, Ruiz-Sánchez MC, Sánchez-Blanco MJ, Torrecillas A (1996) Water relations, growth and yield of Fino lemon trees under regulated deficit irrigation. Irrigation Science 16: 115-23.

Gärdenäs AI, Hopmans JW, Hanson BR, Šimůnek J (2005) Twodimensional modeling of nitrate leaching for various fertigation scenarios under micro-irrigation. Agricultural Water Management 74: $219-242$

Gera KA (2014) North increases area under Kinnow as South set to peel it. Business Standard. Retrieved from http://www.business-standard.com/article/markets/north-ncreases- 
area-under-kinnow-as-south-set-to-peel-it-114042901096_1.html access on $29^{\text {th }}$ April, 2017.

Ghosh SN, Pal PP (2016) Effect of basin versus drip irrigation on quality production in Mosambi sweet orange. Journal of Horticultural Sciences 5: 25-29.

Haneef M, Kaushik RA, Sarolia DK, Mordia A, Dhakar M (2014) Irrigation scheduling and fertigation in pomegranate cv. Bhagwa under high density planting system. Indian Journal of Horticulture 71: 45-48.

Joshi G, Singh PK, Srivastava PC, Singh SK (2012) Effect of mulching, drip irrigation scheduling and fertilizer levels on plant growth, fruit yield and quality of litchi (Litchi chinensis Sonn.). Indian Journal of Soil Conservation 40: 46-51.

Kumar H, Yadav PK, Singh AK, Sharma SK (2013) Evaluation of water regime and fertigation on growth, yield and economics of sweet orange (Citrus sinensis Osbeck) cv. Mosambi. Asian Journal of Horticulture 8: 709-713.

Kusakabe A, White SA, Walworth JL, Wright GC, Thompson TL (2006) Response of microsprinkler-irrigated Navel oranges to fertigated nitrogen rate and frequency. Soil Science Society of America Journal 70: 1623-1628.

Murthy PV (1997) Studies on fertigation in Bangalore Blue grapes-Comparison of source and levels of nutrients. University of Agricultural Sciences, GKVK, Bengaluru.

Navarro JM, Falivene SG (2015) Physiological and nutritional responses of Navel orange trees to different irrigation and fertigation practices. Acta Horticulturae 1065: 1739-1748.

Panigrahi P, Srivastava AK (2017) Water and nutrient management effects on water use and yield of drip irrigated citrus in vertisol under a sub-humid region. Journal of Integrative Agriculture 16: 1184-1194.

Panigrahi P, Srivastava AK, Huchche AD (2012) Effects of drip irrigation regimes and basin irrigation on Nagpur mandarin agronomical and physiological performance. Agriculture Water Management 104: 79-88.

Pattanaaik SK (2017) Response of drip irrigated banana to different irrigation regimes. In: Micro irrigation scheduling and practices, Volume 7, Taylor and Francis Publishing. Pp. 85-98.

Sezen SM, Şengül H, Baytorun N, Daşgan Y, Akyildiz A, Tekin S, Onder D, Ağçam E, Akhoundnejad Y, Gügercin Ö (2015) Comparison of drip-and furrow-irrigated red pepper yield, yield components, quality and net profit generation. Irrigation and Drainage 64: 546-556.

Shirgure PS (2012) Micro-irrigation systems, automation and fertigation in citrus. Scientific Journal Review 1: 156-169.

Shirgure PS, Srivastava AK, Huchche AD, Patil P (2016) Interactive effect of irrigation schedules and fertigation levels on fruit yield, quality and plant nutrition of Nagpur mandarin (Citrus reticulata). Indian Journal of Agricultural Sciences 86: 15091514.

Subramanian P, Krishnaswamy S, Devasagayam MM (1997) Study on the evaluation of drip irrigation in comparison with surface irrigation (basin) in coconut. South Indian Horticulture 45: 255-258.

Suman S, Raina JN (2014) Efficient use of water and nutrients through drip and mulch in apple. Journal of Plant Nutrition 37: 2036-2049.

Wassel AH, Ahmed FF, Ragab MA, Ragab MM (2007) Response of Balady mandarin trees to drip irrigation and nitrogen fertigation. II-Effect of nitrogen fertigation and drip irrigation on fruit setting, number and quality of fruits of Balady mandarin trees (Citrus reticulata). In: 8th African Crop Science Society Conference, El-Minia, Egypt, 27-31 ${ }^{\text {st }}$ October 2007, African Crop Science Society, Pp. 513-522. 